\title{
The Effect of Non Freeze-dried Hydrogel-CHA on Fibroblast Proliferation
}

\author{
Ivan A. Wahyudi ${ }^{1}$, Lea M. Nurwadji ${ }^{2}$ \\ ${ }^{1}$ Departement of Dental Biomedical Sciences, Faculty of Dentistry, Universitas Gadjah Mada, Yogyakarta \\ 55281, Indonesia. \\ ${ }^{2}$ Undergraduate Program, Faculty of Dentistry, Universitas Gadjah Mada, Yogyakarta 55281, Indonesia. \\ Correspondinge-mail to: ivanwahyudi_drg@ugm.ac.id
}

\begin{abstract}
Bone damage can be caused by variety of surgical procedures. Bone reconstruction has been developed lately is tissue engineering techniques. One of materials that proved to be effective as a scaffold in tissue engineering is a hydrogel. The addition of carbonate apatite (CHA) will produce a hydrogel-CHA material which is believed to improve the mechanical properties and biological similarities with the original bone. Scaffold is considered an important aspect in the field of tissue engineering, because it's ability to mimic extracellular matrix of the damaged tissue. Fibroblasts are mesenchymal cells that can be readily cultured in the laboratory and play a significant role in epithelial-mesenchymal interactions, secreting various growth factors and cytokines. On certain condition, Fibroblast will differentiate into bone-forming cells, osteoblasts. Objective: to determine the effect of non freezedried hydrogels - CHA on the number of fibroblasts. Methods: In the treatment groups (hydrogel and hydrogelCHA group), the static seeding, where cells and scaffolds were simply brought into contact, was performed. The other group contained only cells and growth media. Cells were seeded at a density of $2 \times 10^{4}$ cells $/ \mathrm{ml}$ in a 96 -well plate. Number of fibroblasts cell in each group was observed by light microscopy and quantitified by MTT assay on days 1, 2 and 3 post-application. Results: Proliferation of fibroblasts increased significantly on day $3^{\text {rd }}$ after application of non freeze-dried hydrogel - CHA $(p<0.05)$. Conclusion: Application of non freeze-dried hydrogel - CHA may induce fibroblasts proliferation.
\end{abstract}

\begin{abstract}
ABSTRAK
Pengaruh aplikasi non freeze-dried hidrogel-CHA terhadap prolifrasi fibroblas. Kerusakan tulang dapat disebabkan oleh berbagai prosedur bedah. Rekonstruksi tulang yang banyak dikembangkan akhir-akhir ini adalah teknik rekayasa jaringan. Material yang terbukti efektif sebagai perancah dalam rekayasa jaringan adalah hidrogel. Penambahan Karbonat apatit (CHA) akan menghasilkan material hidrogel-CHA yang diyakini dapat meningkatkan sifat mekanis dan kemiripan biologis dengan tulang. Perancah merupakan aspek penting dalam bidang rekayasa jaringan, karena kemampuannya menyerupai matriks ekstraseluler pada jaringan yang rusak. Fibroblas merupakan sel mesenkim yang dengan mudah dibiakkan di laboratorium dan memiliki peran penting dalam interaksi epitel-mesenkimal, mensekresi berbagai faktor pertumbuhan dan sitokin. Pada kondisi tertentu fibroblas akan berdiferensiasi menjadi sel pembentuk tulang yaitu osteoblas. Tujuan: untuk mengetahui pengaruh non freeze-dried hidrogel-CHA terhadap jumlah sel fibroblas. Metode: Pada kelompok perlakuan (kelompok hidrogel dan hidrogel-CHA), penyemaian statis yaitu sel dan perancah dikontakkan. Pada kelompok lain hanya berisi sel dan media pertumbuhan. Sel disemai dengan kepadatan $2 \times 10^{4} \mathrm{sel} / \mathrm{ml}$ dalam 96 sumuran. Jumlah sel fibroblas dalam tiap kelompok diamati dengan menggunakan mikroskop dan dihitung dengan uji MTT pada hari 1, 2, dan 3 setelah aplikasi perlakuan. Hasil: Proliferasi jumlah sel fibroblas meningkat secara signifikan pada hari ke-3 setelah aplikasi non freeze-dried hidrogel-CHA $(p<0,05)$. Simpulan: Aplikasi non freeze-dried hidrogel-CHA dapat meningkatkan proliferasi sel fibroblas.
\end{abstract}

Key words: non freeze-dried hydrogel - CHA, proliferation, fibroblast 


\section{INTRODUCTION}

Bone tissue has a variety of functions; advocates posture, protective vital organs such as those found in the skull and the chest cavity, bone marrow reservoir as a maker of blood cells, including as a means of passive motion. In addition, bone is also a backup storage of calcium, phosphate, and other ions. This specialized connective tissue composed of calcareous material between cells, ie bone matrix and 3 types of cells: osteocytes, osteoblasts, and osteoclasts. ${ }^{1}$ Defects in bone tissue are the most common problem encountered in health fields, including in dentistry. Loss of alveolar bone as tissue structures of supporting teeth can lead to tooth loss, impaired chewing, complicates the installation of prosthesis, and worsen the appearance Large bone defects (critical defect) as a result of the variety of surgical procedures, trauma or variety of congenital and degenerative diseases are not able to regenerate, so that It is necessary to do scientific and clinical reconstruction. And also, it provides the physical and psychological effect on patients' lives. ${ }^{2,3}$

Therapy often used to treat bone defects are the application of bone graft and barrier membrane, which are to induce new bone growth. ${ }^{4}$ A Bone graft can be classified based on the origin of the donor, ie autograft, allograft, xenograft, and alloplastic. Autograft bone is a patient's bone and is the gold standard of bone graft substitutes. The weakness of the autograft is limited in getting the appropriate graft and causing injury in the donor area due to the operation to be performed. Allograft derived from other person, xenografts derived from animals at risk of disease transmission from donor to recipient. Alloplastic have drawbacks related to biocompatibility because the body's reaction to a foreign body may occur. Alloplastic has drawbacks related to biocompatibility because the body's reaction to a foreign body may occur. ${ }^{5}$

Application of Barrier membrane is direct cells replenish the defect space with Guided Tissue Regeneration known (GTR) and Guided Bone Regeneration (GBR). This technique facilitates bone formation due to the barrier membrane will prevent fibrous connective tissue to grow into the defect space and allow only the cells of the bone tissue to fill the defect space. ${ }^{6}$ However, GTR has the disadvantage associated with inadequate flap closure so that GTR treatment indication is very limited. ${ }^{7}$ Advanced bone reconstruction is performed with tissue engineering techniques. One of the factors necessary for the cells can proliferate and differentiate the scaffold with cells that can be planted well. The ideal scaffold must be effectively transport osteoprogenitor cells, capable of providing mechanical support biocompatible and biodegradable. ${ }^{8,9}$ One type of materials that is effectively used as scaffolds in tissue engineering is hydrogels.
Hydrogels can serve as a scaffold that provides structural integrity for bone formation, and have a high degree of tolerance when in contact with body tissues and fluids. ${ }^{10,11}$ Hydrogels have a similar structure and composition of the extracellular matrix. The composition and structure of the hydrogel as a scaffold is expected to function as an artificial extracellular matrix. Extracellular matrix is a hydrophilic matrix 3D micro with two main structures: collagen fibers and filaments proteoglycans. ${ }^{11}$ In the present study, the hydrogel that we used non-freeze dried hydrogels. The method of freeze-dried produce porous hydrogel scaffold. The drawback of the technique of freeze dried is a high degree of difficulty in controlling the porous. So it will be difficult to get a large porous size. ${ }^{12}$ Although, the method of non-freeze dried, just dried hydrogel membrane with a temperature of $40 \mathrm{C}$ in the refrigerator for four days. Using this method, the scaffold will have a lower porous. This can improve the performance of the scaffold as a barrier membrane better because smaller porous can prevent the infiltration of the networks that inhibit bone reconstruction, such as connective tissue. ${ }^{?}$

Carbonate Apatite (CHA) with the chemical formula $\mathrm{CA}^{10}\left(\mathrm{PO}^{4}\right) 6\left(\mathrm{CO}^{3}\right)$ is an effective component of bone mineral, is used as a bone substitute material because of its chemical composition resembles bone tissue and inorganic materials resorption rate is quite high. ${ }^{13,14}$ The incorporation of hydrogels and CHA aims to form a 3D scaffold with an interconnected porous structure that facilitates cell migration so that not only stick and spur the proliferation of fibroblasts. ${ }^{15}$

Fibroblasts are the most common cells of connective tissue that play a role in synthesize collagen, elastin, glycosaminoglycans, proteoglycans, multiadhesive glycoproteins. Fibroblasts used in this study because it is non-immunogenic, easily bred, available and quickly grow. Fibroblasts also have non-tumorigenic fibroblastic cell line properties, namely the potential to differentiate into osteoblastic cells. It is suitable for application in bone tissue engineering. ${ }^{1,16}$

Non-freeze dried hydrogels-CHA was expected to be applied to the bone defect. These applications will result in a hydrogel-CHA direct contact with other cells that are on the oral tissues, such as fibroblasts. The aim of this study was to determine the effect of non freezedried hydrogels - CHA on the number of fibroblasts.

\section{METHODS}

Non freeze-dried hydrogels-CHA preparation

Solid hydrogels removed from the refrigerator $4^{\circ} \mathrm{C}$ and allowed to stand for 30 minutes at room temperature. Briefly solid hydrogels weighing 0.5 grams and mixed with $5 \mathrm{ml}$ of distilled water, wait until all of the 
hydrogels to absorb water and swell (swelling). Then added gradually $0.2048 \mathrm{ml}$ phosphoric acid solution that has been diluted with $5 \mathrm{ml}$ distilled water. Once the hydrogel-CHA homogeneous neutralization process is carried out in order to obtain a neutral $\mathrm{pH}$. Non freeze-dried hydrogel-CHA was made by disc blocks with a diameter of $1.6 \mathrm{~cm}$ and a weight of $150 \mathrm{mg}$. Furthermore, hydrogel-CHA stored in the freezer with $-210 \mathrm{C}$ temperature for 24 hours and then freeze drying is done until the non freeze-dried hydrogel-CHA regardless of the block mold. ${ }^{9}$ The process followed by cross-linking using the method hydrothermal (DHT) 72 hours $140^{\circ} \mathrm{C}$.

\section{In vitro cell proliferation}

Human fibroblasts that taken from male circumcision were a culture in DMEM medium supplemented with 10\% FBS, $2 \mathrm{ml}$ Penicillin Streptomycin, and fungizone as much as $0.5 \mathrm{ml}$, incubated under $5 \% \mathrm{CO}_{2}$ at $37^{\circ} \mathrm{C}$. Membrane hydrogel only and or hydrogel membrane-incorporated CHA sterilized in 96 wells in the microplate wells using sterile tweezers. After that, fibroblasts with a concentration of $2 \times 104$ cells $/ \mathrm{ml}$ of microplate wells included in each using a micropipette.

Fibroblasts were grown on non-freeze dried hydrogels -CHA membranes with controlled and aseptic conditions. Observation of the development and proliferation of fibroblasts was monitored with a digital inverted microscope on day 1,2 , and day 3 .

\section{Cell proliferation test}

MTT assay was carried out to determine the number of cells present on the samples. Absorbance was measured at 550nm using an Elisa Plate reader. Cells number were determined after incubation for day 1,2 and 3 and all experiments were performed in triplicate.

\section{RESULTS}

The fibroblasts were divided into 3 groups, i.e., fibroblasts cells only group (A), fibroblasts plus non freeze-dried hydrogel (B), and fibroblasts plus non freeze-dried hydrogel-CHA (C). Each group was divided into 3 subgroups will be observed the fibroblast proliferation on days 1, 2, and day 3 by ELISA reader. Each group contains $2 \times 10^{4}$ cells $/ \mathrm{ml}$. Group A is a group given only the media and fibroblasts.

Based on Figure 1 in general showed the phenomenon of the most increasing number of fibroblasts in the group of the given non freeze-dried hydrogen-CHA (C). The increasing number of fibroblasts also showed in fibroblasts only group (A) and the group of fibroblasts plus Non-freeze dried hydrogel (B) but less compare to group $\mathrm{C}$.

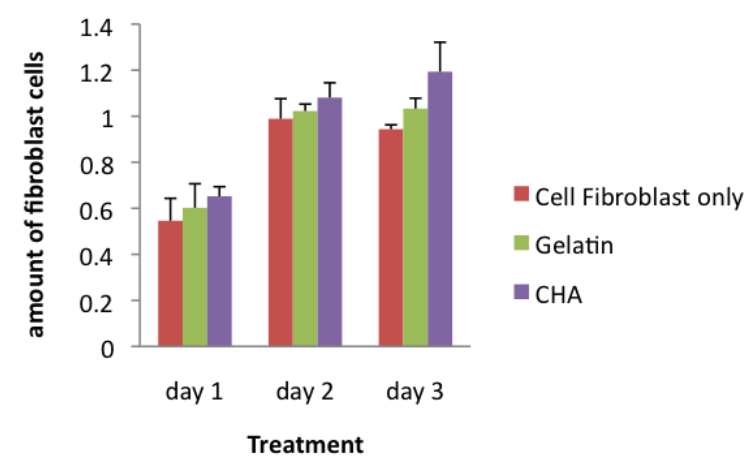

Figure 1. Number of fibroblasts observed on day 1, 2, and 3 after exposure with gelatin or non freeze-dried hydrogelCHA

One-way ANOVA test result showed there was not significance different on day $1(p>0.05)$ but day 2 and day 3 were significance different $(p<0.05)$. This result showed that the application of non freeze-dried hydrogel with or addition-CHA affects an increasing number of fibroblasts. Furthermore, to determine which treatment group had a significant mean difference, further testing is done with Post-Hoc test analysis of LSD (Least Significant Difference).

On day 2, Comparisons between groups A, B and C showed quite different phenomena in the mean number of fibroblasts but statistically were not significance different $(p>0.05)$. On day 3, Fibroblasts cells only group (A) showed significance different $(p<0.05)$ compare to fibroblasts plus non freeze-dried hydrogelCHA (C) but not significance different compare to fibroblasts plus non freeze-dried hydrogel (B) $(p>0.05)$. Group fibroblasts plus non freeze-dried hydrogel (B) and fibroblasts plus non freeze-dried hydrogel-CHA (C) showed not significance different $(p>0.05)$.

\section{DISCUSSION}

The data analysis has been performed quantitatively by counting the number of fibroblasts. In this study, observations were made on days 1, 2, and day 3 . Observation of the length of time for the application according to this research, it has conducted by previous studied. ${ }^{16}$ They said that the fibroblasts did not change the morphological characteristics after incubation days 1, 2 and day 3. Another studied determined that during the process osteoblastic cells grown on the scaffold and suffered proliferation, differentiation, and promotes bone mineralization. ${ }^{17}$ 
In the overall result study showed the phenomenon of an increase in the number of fibroblasts either the 1st, 2nd and 3rd day after application of nonfreeze dried hydrogel only and or non freeze-dried hydrogel-CHA compared fibroblasts without treatment. This is consistent with previous studied which stated that an increase in cell proliferation on given hydrogel treatment compared with not given treatment hydrogel. ${ }^{18}$ Hydrogel as a scaffold has the capability of swelling. The size of the pores in the scaffold increased to facilitate the cells to migrate and grow in the $3 \mathrm{D}$ structure so that not only stick. ${ }^{15}$ Porosity will facilitate cell migration because it provides immunoisolation that allows oxygen, nutrients and metabolic products diffuse into the hydrogel. ${ }^{11}$ Interconnected porous structures serve to replace the old bone pores with new bone. ${ }^{8}$

This study showed that the non freeze-dried hydrogelCHA group (C) had a mean number of fibroblasts is much more than Fibroblasts cells only group (A) and the group of fibroblasts plus non freeze-dried hydrogel (B). Inorganic and organic composition of the hydrogelCHA can stimulate fibroblast proliferation more rapidly. This phenomenon is caused by the hydrogel scaffold that can better cell adhesion thereby increasing migration, proliferation, organization, growth, and regulation of cells in tissue regeneration. ${ }^{11}$ Other studies mentioned components such as calcium-phosphate CHA likely to be a determining factor in the increase in the swelling ability of the hydrogel, thus increasing the surface area, and the number of cells attached more. In addition, the hydrogel as a scaffold must be able to provide an appropriate microenvironment as initial conditions before the onset of tissue damage or the extracellular matrix. ${ }^{11}$ The addition of CHA will provide the appropriate microenvironment to repair damaged bone tissue. The result is in line with our previous study that used vero cell fibroblasts (data not yet published).

Hydrogel-CHA is a porous scaffold is made using the freeze-drying method with thermally induced phase separation by lowering the temperature to encourage the separation of homogeneous polymer solution phase. ${ }^{19}$ Dehydrothermal (DHT) is a method of the physical crosslinking covalent inter-chain polypeptide of collagen fibers at high temperature and vacuum. ${ }^{20}$ Methods dehydrothermal (DHT) to serve the resulting elimination of water molecules and allowing cross-reactions take place throughout the process. Vacuum conditions required to avoid denaturation of collagen caused by the presence of water. ${ }^{21}$ Dehydrothermal crosslinking with a growth rate of cells is much greater than the crosslinking with glutaraldehyde. ${ }^{21}$ The combination of freeze drying and dehydrotermal (DHT) aims to provide sufficient mechanical strength to prevent damage to the pores during drying, and produces a matrix with porosity (interconnected porous) more than $90 \% .{ }^{20}$ Freeze drying and crosslinking can alter osteoblastic response through modification of the scaffold. ${ }^{17}$

\section{CONCLUSION}

Application of non-freeze dried hydrogel - CHA can increase the amount of fibroblasts proliferation.

\section{ACKNOWLEDGMENT}

We acknowledge Dr. Ika Dewi Ana for kindly giving the material of hydrogel-CHA.

\section{REFERENCES}

1. Junqueira LC, Carneiro J. Histologi Dasar (terj.), Penerbit Buku Kedokteran EGC, Jakarta. 2007. p.134-5. Indonesian.

2. Wahl DA, Czenuszka JT. Collagen-hydroxiapatite composites for hard tissue repair. Eur Cell Mater. 2006; 11: 43-56.

3. d'Aquino R. Human mandible bone defect repair by the grafting of dental pulp stem/progenitor cells and collagen sponge biocomplexes. Eur Cell Mater. 2009;18:75.

4. Sukumar S, Drizhal I. Bone graft in periodontal therapy. Acta Med. 2008;51:203-7.

5. Spiekermann H. Color Atlas Of Dental Medicine, Thieme Medical Publisher, New York. 1995. p.12.

6. Lieberman JR, Friedlaender GE. Bone Regeneration and Repair, Humana Press Inc.:New Jersey. 2005. p. 367.

7. DeCarlo AA, Whitelock JM. The role of heparan sulfate and perlecan in bone-regenerative procedures. J Dent Res. 2006;85:122-32.

8. Yoshikawa H, Myoui A. Bone tissue with porous hydroxiapatite ceramics. J Artif Organs.2005;8:131-6.

9. Young S, Wong M, Tabata Y, Mikos AG. Gelatin as a delivery vehicle for the controlled release of bioactive molecules. J Control Release. 2005;109:256-74.

10. Darwis D. Role of radiation processing in production of hydrogels for medical applications. Atom Indonesia. 2009;35:85-104.

11. Slaughter BV, Khurshid SS, Fisher OZ, Khademhosseini A, Peppas NA. Hydrogels in regenerative medicine. Adv mater. 2009;21:330729.

12. O’Brien FJ, Harley BA, Yannas IV, Gibson L. Influence of freezing rate on pore structure in freeze-dried collagen-GAG scaffold. Biomaterial. 2004;25:1077-86.

13. Fisher JP, Mikos AG, Bronzino JD. Tissue Engineering, CRC Press, Florida. 2007. p. 4-5, 8-11. 
14. Filippov YY. Carbonate subtituted hydroxyapatite (CHA) powder consolidated at $450^{\circ} \mathrm{C}$. J. Phys. 2011;291:1.

15. Ratanavaraporn J, Damrongsakkul S, Sanchavanakit N, Banaprasert T, Kanokpanont $\mathrm{S}$. Comparasion of gelatin and collagen scaffolds for fibroblast cell culture. J Met Mater Miner. 2006;16:32.

16. Goncalves EM, Ventura CA, Yano T, Macedo MLR, Genari SC. Morphological and growth alterations in Vero cells transformed by cisplatin. Int J Cell Biol. 2005;30:486.

17. O'Chen $\mathrm{T}$, Chen K. Investigation and application progress of Vero cell serum-free culture. Int J Cell Biol. 2009;1:41.
18. Kim HW, Knowles JC, Kim HE. Hydroxyapatite and gelatin composite foams processed via novel freeze-drying and crosslinking for use as temporary hard tissue scaffolds. J Biomed Mater Res. 2003;72A:136.

19. Ikada Y. Tissue Engineering Funadamental and Applications. Elsevier Ltd., Oxford UK. 2006. p. 3,4,189.

20. Kinikoglu B, Rodri'gues-Cabello CJ, Damour O, Hasirci VA. Smart bilayer scaffold of elastinlike recombinamer and collagen for soft tissue engineering. J Mater Sci. 2011;22: 1541-4.

21. Madaghiele M, Piccinno A, Saponaro M, Maffezzoli A, Sannino A. Collagen and gelatinebased films sealing vascular prosthese. J Mater Sci. 2009; 20: 1979-89. 